\section{Self-efficacy as a mediator of the relationship between subjective well-being and general health of military cadets}

\author{
A autoeficácia como mediadora da relação \\ entre bem-estar subjetivo e saúde geral \\ de cadetes militares
}

\author{
La autoeficacia como mediador en la relación \\ entre salud general y bienestar subjetivo de \\ los cadetes militares
}

1 Instituto de Educação Superior da Paraíba, João Pessoa, Brasil.

2 Universidade Federal da Paraíba, João Pessoa, Brasil.

3 Faculdades de Enfermagem e Medicina Nova Esperança,

João Pessoa, Brasil.

Correspondence

T. J. S. Lima

Rua Lindolfo G. Chaves 393 apto. 101, João Pessoa, PB 58051-200, Brasil.

tiago.souzalima@outlook.com

\begin{abstract}
The objective of this study is to investigate the role of self-efficacy beliefs as a mediator of the relationship between the subjective well-being and general health of military cadets (police and firefighters). For this study, 228 cadets participated, the majority being Military Police officer candidates (65\%), male (79\%), between 17 and 34 years of age (99\%), and unmarried (74\%). They responded to questionnaires on general health (GHQ-12), perceived general self-efficacy, to the multiple scales that cover subjective wellbeing, and demographic questions. Initial regression analyses indicate the predictive power of subject well-being regarding general health. Subsequently, the mediation analyses provide satisfactory evidence for the role of perceived self-efficacy as a mediator of the relationship between the subjective well-being variables and the overall health of military cadets. The implications of these results for the professional training of the cadets are discussed.
\end{abstract}

Self Efficacy; Mental Health; Military Personnel
Luciane Albuquerque Sá de Souza 1 Ana Raquel Rosas Torres 2 Genário Alves Barbosa 3 Tiago Jessé Souza de Lima 2 Luana Elayne Cunha de Souza ${ }^{2}$

\section{Resumo}

O objetivo do presente estudo é investigar o papel da crença na autoeficácia como mediadora da relação entre o bem-estar subjetivo e a saúde geral de cadetes militares (policiais e bombeiros). Para tanto, participaram 228 cadetes, sendo a maioria de oficiais da Polícia Militar (65\%), do sexo masculino (79\%), com idades variando entre 17 e 34 anos (99\%), e declarados solteiros (74\%). Estes responderam às medidas de saúde geral (QSG-12), autoeficácia geral percebida, as múltiplas escalas que compõem o bem-estar subjetivo e perguntas demográficas. Análises iniciais de regressão apontam o poder preditivo do bem-estar subjetivo sobre a saúde geral. Posteriormente, as análises de mediação fornecem evidências satisfatórias para o papel da crença na autoeficácia como mediador da relação entre as variáveis do bem-estar subjetivo e a saúde geral de cadetes militares. As implicações destes resultados na formação dos cadetes são discutidas.

Autoeficácia; Saúde Mental; Militares 
Certain work activities, due to their characteristics, expose individuals to various contingencies that may lead to higher physical and mental suffering compared to other professions. This is the case, for example, for military corps state police and firefighters, who are placed at risk of violence and death, besides having to deal with poor working conditions resulting from an often deficient public structure. These factors can cause occupation-specific illnesses, as well as determine the general health of the worker 1 .

In this context, training is necessary that equips these professionals with coping strategies for such situations. Academic training in the Officer Training Program seeks to provide technical and professional knowledge to future officers in these military corps. Additionally, the individual assumes the post of military cadet, proceeding to carry out, in addition to student activity, internal and external activities linked to training, for example, policing (Police), civil defense, fire prevention and firefighting, search and rescue (Fire \& Rescue) 2,3. Thus, the cadets begin to live under a system of military rules and principles that guide these organizations 4 .

In addition to this training, individual aspects are relevant in coping with stressful situations, because whether or not an event that generates tension causes an anxiety reaction depends on the way the individual interprets the situation and on the coping skills of the person ${ }^{1}$. Bandura 5 states that a person's attitudes, abilities, and cognitive skills play a key role in how the person perceives and behaves in different situations. In this sense, perceived self-efficacy plays a central role in this relationship. According to this author, self-efficacy is defined as a belief that the individual has in his/her ability to gather cognitive, motivational, affective, and behavioral resources needed to achieve a certain goal or to perform a task, being fundamental to the acquisition and maintenance of adaptive behavior patterns.

Based on this context, the aim of the present study is to investigate the role of self-efficacy beliefs as a mediator between subjective well-being and general health of military cadets (police and firefighters). More specifically, we are attempting to understand the mediating role that perceived self-efficacy plays between variables experienced in the study/work context (such as positive and negative affects, subjective vitality, job satisfaction, corps type and length of service) and the general health of police and firefighter military cadets in a capital city in Northeastern Brazil.

\section{Perceived self-efficacy}

Perceived self-efficacy is a central aspect of Social Cognitive Theory (SCT) 5. In SCT, self-development and behavior change are explained from a basic principle: human agency. According to Bandura 6 , to be an agent means to influence the actual functioning and circumstances of life, intentionally. According to this view, people are proactive, self-regulating, and self-reflexive. SCT proposes a relationship based on a model of triadic reciprocity where personal variables, environmental factors, and behavior operate as interactive and reciprocal determinants, mutually influencing one another 7 . Through this interaction, it is thought that the individual is able to act on his/her surroundings. According Bandura 8, this active behavior works through a key mechanism, known as self-efficacy beliefs. These are the beliefs that individuals have about their ability to organize and carry out behaviors necessary to achieve their goals and objectives 9 .

Self-efficacy beliefs help individuals deal with a social reality that requires constant confrontation with difficulties, obstacles, and impediments 9 . These beliefs determine how people feel, think, motivate themselves, and behave, acting as mediators in four different levels. Cognitive processes are considered as the first type of mediating function of perceived self-efficacy, because they influence the use of a pattern of behaviors, being responsible for the development of rules that: (a) predict and influence certain events; (b) set goals and strategies; (c) anticipate the possibility of achieving success in these goals; and (d) determine effectiveness in problem solving. The second level occur when people intend to successfully employ a particular behavior pattern avoiding (in a biased manner) certain situations that exceed their abilities; in this case, people seek to undertake activities and choose environments in which they believe they can employ behavior that is in their interest 7 . In other words, self-efficacy beliefs affect the choice of activities and environments influencing the individual performance.

Affective processes are the third type of mediating function, since perceived self-efficacy determines the form and the intensity of affective reactions to the events that people consider of vital importance, thus influencing their thoughts and intended actions 7,9. Finally, the fourth mediating function of self-efficacy is the motivational processes that influence the individual's intention to employ the proposed behavior, the effort that will be put forth, and the persistence in the face of difficulties that may possibly come into play 5 . 
Bandura 10 emphasizes that a strong sense of self-efficacy enhances human accomplishment and personal well-being in many ways, being related to how people feel, think, and act. In terms of feelings, a sense of low self-efficacy is associated with depression, anxiety, and helplessness, as well as with low self-esteem and negative feelings about their achievements and personal development. In terms of thinking, a strong sense of competence facilitates cognitive processes and academic performance 11 .

People who believe in their capabilities approach difficult tasks as challenges to be mastered rather than as threats to be avoided, and establish challenging goals and maintain a strong commitment to them. Once an action has been taken, they invest more effort and persist longer than those with low self-efficacy. In contrast, people who doubt their capabilities become discouraged when facing difficult tasks, which they see as personal threats. These individuals have low aspirations and a weak commitment to the goals they choose to pursue. Nevertheless, perceived self-efficacy is not a positive illusion, nor unrealistic optimism, since it is based on experience and does not lead to making irrational decisions about the risks of a task 10 .

Since the work of Bandura ${ }^{5}$ on SCT, perceived self-efficacy has been used in various fields such as school performance, emotional disorders, career choice, and mental and physical health ${ }^{6}$. In the relationship between perceived self-efficacy and health, the former, along with other components of SCT, such as outcome expectancies, has emerged as one of the most important predictors of a number of health-related behaviors in a diverse range of studies 12,13,14. Perceived selfefficacy is directly related to the adoption and the promotion of healthy behaviors, e.g., prevention of unsafe sexual behavior 15,16, getting regular physical exercise 17 , proper nutrition and weight control 18 , and smoking cessation ${ }^{19}$. It is also related to the positive and negative affects and strategies for coping with stress 14,20 .

Such studies have shown that a high sense of self-efficacy is related to protective behaviors, to the promotion of healthy behaviors, and generally to better levels of health, while low self-efficacy is related to the use of coping strategies focused on emotions such as denial and self-blame 21, as well as to symptoms of anxiety, depression, distress, psychosomatic symptoms, and negative well-being 7,22,23.

\section{Subjective well-being, self-efficacy, and general health}

Because of the characteristics specific to their professions, police and firefighters are more susceptible to developing occupational stress 24,25 , as they also present high levels of physical and mental suffering 26,27. These aspects contribute to poor overall health. Thus, to understand the level of overall health of a given population, experiences, feelings, and assessment of job satisfaction are relevant variables. The domains cited above are part of what is called subjective wellbeing. Subjective well-being is defined as a cognitive and affective assessment that people make of their life, encompassing a broad category of phenomena that includes emotional responses, satisfaction in different domains, (such as work and school), and overall judgments of satisfaction with life.

According to Ryan \& Deci 28 , it is possible to understand well-being as a state of full functioning and adequate psychological experience, referring not only to the absence of disease but to a state of inner satisfaction, i.e., with oneself and with one's surrounding environment. Well-being can be understood from a large variety of measures (such as: psychological distress, fatigue, life satisfaction, vitality, positive affects, and negative affects), and this can be explained (in part) by the breadth of its own definition, as well as by the multiple factors that determine it.

Being a relevant indicator of mental wellbeing, and relatively stable over time, subjective well-being has cumulative influences on overall health and longevity, and is therefore important for research in health psychology 29. A literature review concluded that high levels of subjective well-being predict individuals' future health as well as the quality of their social life ${ }^{30}$. Diener \& Chan 29 , in reviewing a study with different methodologies (correlational, longitudinal, experimental), note that the influence of subjective well-being on health and longevity is convincing, and that high levels of subjective well-being increase a person's life expectancy from four to ten years, compared to those with low levels.

Nevertheless, the relationship between subjective well-being and general health can be influenced by mediating variables, as may be the case for perceived self-efficacy. Sense of selfefficacy is related to both general health and to various dimensions of subjective well-being. For example, high self-efficacy is related to control over stress processes, to greater self-esteem, to increased general health, better well-being, and better condition physically and in the recovery from acute and chronic illnesses 5,31,32. Low 
self-efficacy is more related to symptoms of anxiety and depression 33 , and low levels of subjective well-being 34 .

Thus, perceiving a situation as threatening will depend on the way the individual interprets that situation and on his/her coping skills, not only with the context but also with certain relevant individual factors. In this sense, taking into account the importance of perceived self-efficacy in the promotion and maintenance of healthy behaviors, it is proposed that self-efficacy takes on a mediating role between cognitive and affective evaluations of the means, that is, the subjective well-being and the general health of the individual. Those individuals with higher self-efficacy will assess, cognitively and affectively, their lives as better, thus having a positive impact on overall health, while individuals with lower self-efficacy will tend to have a worse assessment of their lives and consequently poorer overall health.

\section{Method}

\section{Participants}

A total of 228 cadets, from a population of 233 regularly enrolled in a military academy, participated in this study. Most of the participants were men $(79 \%)$, ranging in age from 17 to 35 years $(99 \%)$, with a mean age of 24 years $(\mathrm{SD}=0.85)$, and unmarried (74\%). Of this total, $65 \%$ were enrolled in the Military Police Officer Training Program and $35 \%$ were in the program for Military Firefighters, with $42 \%$ being in their first year, $30 \%$ in their second, and $28 \%$ in their third year.

\section{Instruments}

Participants received a booklet containing the instruments described as follows:

- General Health Questionnaire (GHQ-12) 35. Composed of 12 items (e.g., Have you been feeling capable of making decisions?), where the respondent reports the extent of having experienced the proposed symptoms, to evaluate psychiatric morbidity. For the negative items the response alternatives range from $1=$ not at all to $4=$ much more than usual; whereas for the positives, the responses range from $1=$ more than usual to $4=$ much less than usual. A higher score is an indication of a lower level of overall health.

- Perceived General Self-efficacy Scale 36. Composed of 10 items that relate to the achievement of goals and the ability to handle difficult demands in everyday life (e.g., I can remain calm when facing difficulties because I can rely on my coping abilities). It is answered on a 5-point scale, ranging from $1=$ not at all true to $5=e x$ actly true.

- Positive and Negative Affect Schedule (PANAS) 37. Composed of ten adjectives that indicate affective states, four positive (happy, joyful, pleased, and amused) and five negative (depressed, worried, frustrated, angry, and unhappy). The adjective "optimistic" was added to balance the scale 38 . The instrument evaluates how much the participant has experienced each of these emotions in the past month, using a seven-point response scale, ranging from $1=$ not at all to 7 = very much .

- Subjective Vitality Scale (SVS) 39. Assesses the degree to which participants have been feeling physically and mentally vigorous and alert in the past month. The SVS consists of seven items (e.g., I have energy and determination; I feel alive and full of vitality), which is answered on a sevenpoint scale ranging from $1=$ not at all true to 7 = completely true.

- Satisfaction with Life Scale (SWLS) 40. The SWLS consists of five life satisfaction assessment items (e.g., In most ways my life is close to my ideal). Responses are graded on a 7-point Likert scale ranging from $1=$ strongly disagree to $7=$ strongly agree.

In addition to these instruments, all participants completed a sociodemographic questionnaire that included gender, age, type of training program (Military Police - MP or Military Firefighter-MF), and time enrolled in the program).

\section{Procedure}

After consent and authorization from the Military Police Education Center, data was collected by properly trained employees. To approach the cadets (MP and MF) in the Officer Training Program, the data collection team requested their voluntary cooperation to participate in a study concerning the factors related to their overall health. The need for individual responses was emphasized, indicating that all information was confidential, and that the answers would only be treated statistically in the aggregate, ensuring their anonymity and confidentiality, in accordance with Resolution n. 196/96 of the National Health Council. On average, 20 minutes was enough to complete each participant's entry.

\section{Data analysis}

Initially, an Enter method hierarchical regression was run to evaluate whether sociodemographic variables and subjective well-being predicted the general health of the cadets. Subsequently, simple regressions were run, using the Enter method, 
to test the mediating effect of self-efficacy among the aforementioned variables.

A given variable is taken as a mediator if it has the capacity to explain all or part of the relationship between an independent and a dependent variable 41 . To test mediation, the independent variable (IV) causal effect on the dependent variable (DV) is partitioned into two paths, a direct effect (c), and an indirect effect (c'), which is controlled by the mediator $(\mathrm{M})$. Furthermore, the effect of the IV on the mediator (a) and the effect of the mediator on the DV (b) are also computed. In order to test the mediation hypothesis, the method popularized by Baron \& Kenny 41, known as causal steps strategy, is usually followed, in which the paths described above are estimated by regression, based on some set criteria for being a mediation. Initially, the relationships between IV and $\mathrm{M}$ (a), between the M and DV (b), and between IV and DV (c) must be significant. Subsequently, when you introduce the mediator into the relationship, the predictive power of the IV, when controlled by M, must be zero or less than its direct effect on the DV. Taking these relations into account, we can assess which type of mediation is present in the model.

When the direct effect (c) is greater than the indirect (c'), and both are directly related (i.e., they both have positive or negative signs), and path c is significant and path c' is not, we have a full mediation. The introduction of $\mathrm{M}$ into the relationship turns the predictive power of the IV on the DV insignificant, i.e., the relationship between them is totally explained by the mediator. While in a partial mediation, the paths $\mathrm{c}$ and c' are both significant and directly related (same sign), and upon introducing $M$, the relationship between IV and DV decreases, but remains significant ${ }^{42}$. Baron \& Kenny 41 indicated that additional procedures (Sobel test) are required to examine the magnitude of the mediating effect and its statistical significance.

The Sobel 43 test takes into account the product of paths $a b$ divided by the standard error of this cross-product to yield a $\mathrm{Z}$ statistic that can be evaluated for statistical significance using probabilities corresponding to the standard normal distribution 43 . However, the product of two normally distributed variables is not itself normally distributed, and the product of paths $a$ and $b$ tends to be asymmetric and highly kurtotic 43 . Thus, the corresponding $\mathrm{Z}$ test lacks statistical power relative to methods that attempt to correct for this asymmetry 44 .

Additionally, bootstrap methods are generally recommended since they do not impose the assumption of normality. Bootstrapping is a computational method that involves repeatedly sampling from the data set and estimating the indirect effect in each resampled data set thousands of times, creating an empirical approximation of the sampling distribution of $a b$, used to construct confidence intervals for the indirect effect 45 . Because confidence limits are important for understanding effects, confidence limits based on the bootstrap are recommended 44 and preferred to the Sobel test 45 . To corroborate the mediation hypothesis, the confidence intervals created should not contain zero value. That is, the indirect effects are different from zero.

In the present study, the mediation analyses were performed using the PROCESS, a macro for SPSS developed by Hayes 46. For bootstrap, 1,000 samples are computed and the bias corrected and accelerated (BCa) method was employed to generate the confidence intervals for indirect effects.

\section{Results}

First we assessed the internal consistency of the measures with Cronbach's alpha $(\alpha)$. The positive affects obtained $\alpha=0.87$, and the negative affects $\alpha=0.83$. The SVS presented $\alpha=0.93$, the SWLS obtained $\alpha=0.78$. The GHQ was used as a unifactorial measure and presented $\alpha=0.87$; in the same manner, the Perceived General Self-Efficacy Scale obtained $\alpha=0.86$.

We then ran hierarchical regression analyses using overall health as the DV. The variables included in the first block were gender, corps type, and length of corps service. The SWB variables (positive affects, negative affects, subjective vitality, and life satisfaction) were included in the second block. Table 1 shows the regression results.

\section{Table 1}

Parameters estimated according to hierarchical regression modeling.

\begin{tabular}{|c|c|c|}
\hline Predictors & Model 1 & Model 2 \\
\hline Gender & 0.09 * & $0.06 \mathrm{~ns}$ \\
\hline Corps type & $-0.16 \mathrm{~ns}$ & $-0.05 \mathrm{~ns}$ \\
\hline Corps length of service & 0.16 * & $-0.07 \mathrm{~ns}$ \\
\hline Positive affects & & $-0.19 * *$ \\
\hline Negative affects & & $0.26 * \star \star$ \\
\hline Subjective vitality & & $-0.24 * \star \star$ \\
\hline \multirow[t]{3}{*}{ Satisfaction with life } & & $-0.26 * \star \star$ \\
\hline & $\mathbf{R}^{\mathbf{2}}$ adjusted & $\mathbf{R}^{\mathbf{2}}$ adjusted \\
\hline & 0.045 & 0.646 \\
\hline
\end{tabular}

ns: non-significant;

* $p<0.05$;

** $\mathrm{p}<0.01$;

$\star \star * p<0.001$ 
As can be seen in Table 1, in the first equation, the sociodemographic variables showed a significant predictive ability regarding general health $\left[R^{2}=0.045 ; F(3,219)=4.47 ; p<0.01\right]$, with only the gender and length of service variables predicting overall health: women present a lower level of overall health, and the longer the length of service the lower the level of overall health, since a higher score on the GHQ is indicative of a lower level of health. However, in the second equation, upon introducing the subjective wellbeing variables, the sociodemographic variables cease to be significant, and leave only those from the first equation $\left[R^{2}=0.657 ; F(7,215)=58.77\right.$; $\mathrm{p}<0.001]$. Moreover, this second model resulted in a significant increase in the percentage of explained variance of general health $\left[R^{2}\right.$ Change $=$ 0.588 ; FChange $(4,215)=93.80, \mathrm{p}<0.001]$. Therefore, the subjective well-being variables signifi- cantly predict overall health beyond the effects of the sociodemographic variables.

Subsequently, simple regression analyses were run to test the hypothesis that self-efficacy mediates the relations obtained above. It should be noted that we decided to work with a unifactorial solution of the GHQ-12, taking into account a more parsimonious representation of psychological discomfort 47 . The results of these analyses are shown in Figure 1.

Taking into account the subjective wellbeing variables, it is noteworthy that the three criteria proposed by Baron \& Kenny 41, for mediation to occur, were met, indicating that selfefficacy mediates their relationship with overall health. The regression runs are shown in Figure 1 with the standardized coefficients $(\beta)$, all being significant.
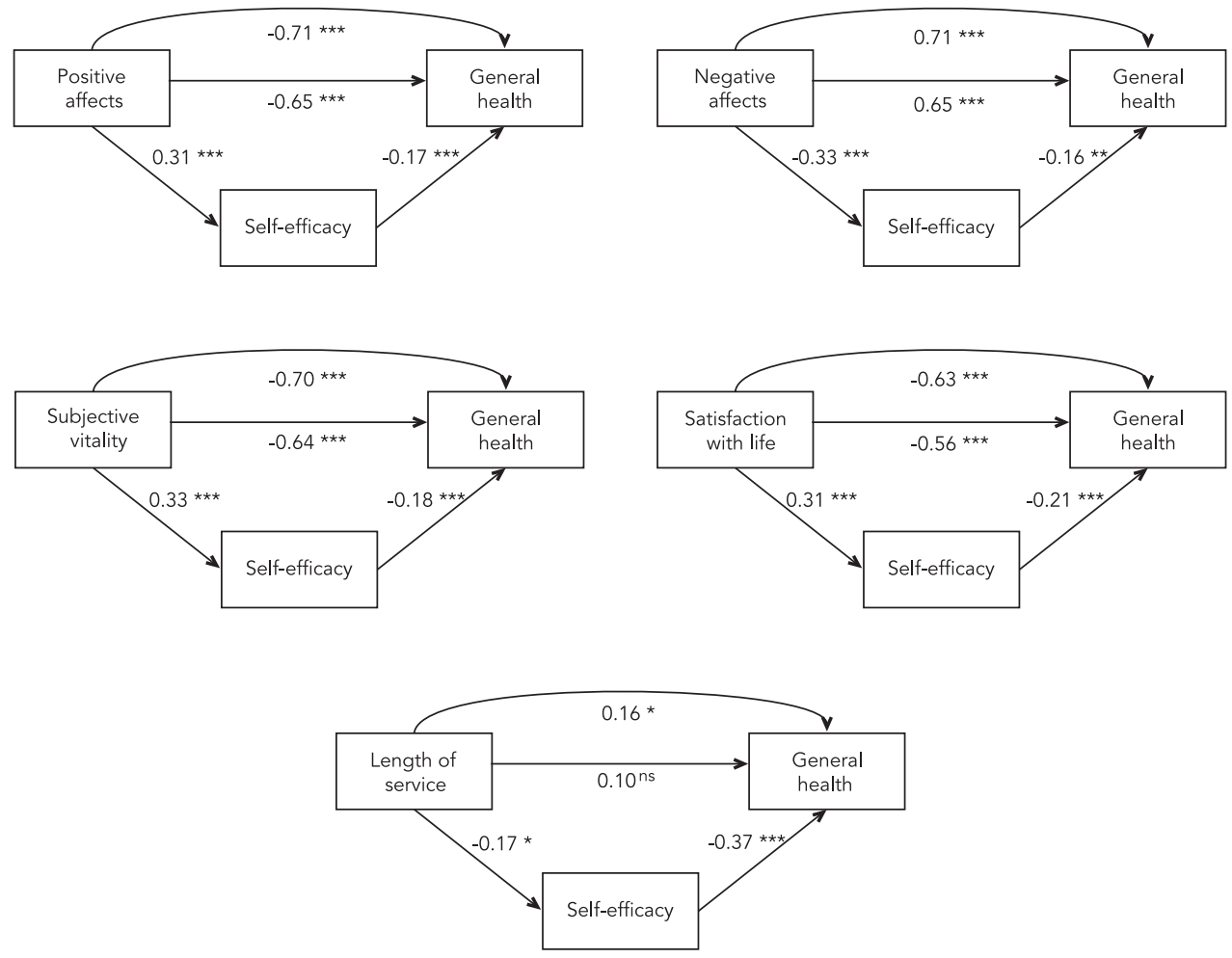

\footnotetext{
ns: non-significant

* $p<0.05$

** $p<0.01$;

$\star \star \star ~ p<0.001$
} 
However, while self-efficacy, in general, may act as a mediator between the subjective well-being variables and general health, it is a partial mediation since both paths, $\mathrm{c}$ and c', are significant for all mediations. A partial mediation indicates that the mediator is responsible for only a portion of the explained variance in the relationship between the IV and DV. Moreover, as can be seen in Table 2, the other criteria employed corroborate the initial findings, since Sobel's $\mathrm{Z}$ was significant for these variables $(p<0.01$ ), indicating that the indirect effects are significant, and in the bootstrapping analysis, the confidence intervals do not contain zero value, i.e., the indirect effects are significantly different from zero.

With regard to the sociodemographic variables, self-efficacy only mediated the relation with length of service in the corps. In addition, this is a full mediation, since the c' path becomes non-significant, indicating the relationship between length of service and general health is totally explained by self-efficacy. Sobel's Z test and bootstrapping were both significant. With respect to gender, it was not possible to assess mediation, since gender was not significantly associated with self-efficacy $(b=-0.11 ; p=0.09$ ).

\section{Discussion}

The main objective of this study was to investigate the role of self-efficacy beliefs as a mediator between subjective well-being and general health. Initial regression analyses corroborate the predictive power of subjective well-being on general health, and subsequent mediation analyses provide satisfactory evidence for the role of perceived self-efficacy as a mediator between the aforementioned variables, corroborating other studies that have employed it as a mediator between variables different from the ones studied here 48,49 .

Self-efficacy, as a belief in one's own ability to organize and execute courses of action, acts as a buffer in that the perception of a situation as threatening will depend on the way the individual interprets it, and on his/her coping skills. Therefore, one can conclude that the perception that individuals have about their abilities to take satisfactory courses of action regulates the cognitive and affective evaluations (i.e., their subjective well-being) that individuals make about their life or their work, thus influencing their overall health.

Recent studies with samples of police officers and firefighters have demonstrated that they are more likely to show symptoms of occupational stress 24,25 , have high levels of physical and mental suffering 26,27, and exhibit higher alcohol consumption compared with the general population 50. These professionals are repeatedly exposed to dangerous situations, risking their own lives in order to save the lives of others and/or defend society's public and private properties. Thus, the working conditions in both corps are not conducive to good levels of health for these officials. And it is in this deleterious environment that the military cadets take up living, besides having to take care of all the academic activities related to the program, during their training period. This school/work context can therefore begin to compromise, early on, the well-being and health of these public safety and social defense professionals.

In this sense, one can identify at least two levels where the sense of self-efficacy plays an influential role in the health of these professionals ${ }^{10}$. At the most basic level, people's beliefs in

Table 2

Test of indirect effects considering the Sobel test and Bootstrapping.

\begin{tabular}{|c|c|c|c|c|}
\hline \multirow[t]{2}{*}{ Variables } & \multirow[t]{2}{*}{ Sobel test (Z) } & \multirow[t]{2}{*}{ Point estimate } & \multicolumn{2}{|c|}{ Bootstrapping (BCa $95 \% \mathrm{Cl}$ ) } \\
\hline & & & Lower & Upper \\
\hline Positive affects & $-2.84 *$ & $-0.0282 * \star$ & -0.0517 & -0.0094 \\
\hline Negative affects & 2.74 * & $0.0243 * \star$ & 0.0099 & 0.0440 \\
\hline Subjective vitality & -2.94 * & -0.0232 ** & -0.0433 & -0.0098 \\
\hline Satisfaction with life & -3.09 * & $-0.0350 * \star$ & -0.0659 & -0.0158 \\
\hline Corps length of service & $2.32 \star \star$ & 0.0421 ** & 0.0134 & 0.0852 \\
\hline
\end{tabular}

Note: based on 1,000 samples of bootstrapping

$\mathrm{BCa}=$ bias corrected and accelerated; $95 \% \mathrm{Cl}$ : $95 \%$ confidence interval.

* $p<0.01$;

** $p<0.05$ 
their ability to handle stressful situations activate biological systems that mediate health and illness. For social cognitive theory, stress reactions are viewed in terms of perceived ineffectiveness of control over ambient physical threats and demands. If people believe that they can effectively deal with potential stressors, they will not be disturbed by them. But if they believe they can not control aversive events, they tend to be distressed, impairing their level of functioning. Another way in which efficacy beliefs can affect health is related to direct control over healthy habits. The stronger the sense of self-efficacy, the more likely it is that people take up and sustain the effort required to adopt and maintain behaviors that promote health.

Perceived self-efficacy also served as a mediator between length of service in the corps and mental health, this relationship being totally explained by self-efficacy. Given these results, we propose that academic practices be rethought in order to facilitate a more conducive environment in which the time and workloads of the academic studies and work activities performed by students are better distributed. The training should not only provide cadets the essential skills and knowledge for professional practice, but also provide the development of self-regulatory mechanisms that allow for a greater sense of selfefficacy. Thus, exposure to positive experiences of success, vicarious experiences of observing the successful performance of others, and verbal persuasion and other social influences that reinforce appropriate behaviors are strategies that can be adopted to strengthen the cadets' sense of self-efficacy. In this way, the academy will also be contributing to the mental health of their future police and firefighting officials.

\section{Final considerations}

This study contributed to a better understanding of factors that influence the mental health of military cadets, namely individual characteristics, such as perceived self-efficacy, and evaluative and situational aspects, such as the subjective well-being variables (positive affect, negative affect, subjective vitality, and life satisfaction). Nevertheless, some limitations can be pointed out.

Although the sample used here represents almost the entire population of the academies studied (cadets from academies for military police and military firefighters), one should be cautious in generalizing the results to other training academies, because the school/work environment is variable, given that these military corps are not standardized at the national level. Future studies may take into account samples from other military academies (aeronautics, firemen, army, navy and police) in other states. Other studies might assess more accurately the influence of length of service in the corps on general health and whether the mediating role of perceived selfefficacy varies with service time, as it is expected that the longer the individual is exposed to negative situations, the lower his/her resulting overall health. Other studies can also focus on individual differences. Although, in the present study, it may not have been observed that the cadet's gender significantly predicts overall health, when taken together with the subject well-being variables, other studies suggest that women are more likely to have problems related to psychological wellbeing, especially if they are lesser in number 51 , as is generally the case in military academies.

Thus, this study reinforces the need to expand research in the field of health of military officials, especially of military cadets, as yet little has been properly discussed about the study/work conditions of these individuals. 


\section{Resumen}

El presente estudio pretende investigar el papel de la creencia en la autoeficacia como mediador en la relación entre el bienestar subjetivo y la salud general de los cadetes militares (policía y bomberos). La muestra estuvo formada por 228 cadetes, siendo la mayoría de agentes de la policía (65\%), hombres (79\%), con edades comprendidas entre 17 y 34 años (99\%), y declarados solteros (74\%). Se utilizó un cuestionario con variables de salud general (QSG-12), autoeficacia general percibida, múltiples escalas que componen el bienestar y cuestiones sociodemográficas. El análisis inicial de regresión mostró que el bienestar es un predictor de la salud general. Posteriormente, los análisis de mediación mostraron satisfactoriamente ante el papel la creencia en la autoeficacia como mediador de la relación entre las variables del bienestar y la salud general de los cadetes militares. Se discuten las implicaciones de estos resultados en la formación de los cadetes.

Autoeficacia; Salud Mental; Personal Militar

\section{Contributors}

L. A. S. Souza helped draft the introduction and discussion of the data, and was responsible for data collection as well. A. R. R. Torres contributed by critically reviewing the theoretical content, data analysis, discussion of results, and final revision of the manuscript. G. A. Barbosa participated in the discussion of the results, in addition to collaborating in the data collection. T. J. S. Lima collaborated in drafting the introduction, data analysis, and discussion of results. L. E. C. Souza contributed in the data analysis, description of results, preparation of tables and figures, and text revision.

\section{References}

1. Dela-Coleta ASM, Dela-Coleta MF. Fatores de estresse ocupacional e coping entre policiais civis. Psico USF 2008; 13:59-68.

2. Polícia Militar. Edital no 001/2012 CFO PM-2013. Concurso público para o curso de formação de oficiais da Polícia Militar do Estado da Paraíba. http://www.pm.pb.gov.br/downloads_concur sos/CFO_6_1_28_06_2012.pdf (acessado em 30/ $\mathrm{Jul} / 2013)$.

3. Corpo de Bombeiros Militar da Paraíba. Edital n. 001/2012 CFO BM-2013. Concurso para o curso de formação de oficiais 2013 do Corpo de Bombeiros Militar do Estado da Paraíba. http://www. bombeiros.pb.gov.br/concursos (acessado em 30/ $\mathrm{Jul} / 2013)$
4. Paraíba. Lei estadual no 7.605 , de 28 de junho de 2004. Diário Oficial do Estado da Paraíba 2004; 29 set.

5. Bandura A. Social learning theory. New Jersey: Prentice Hall; 1977.

6. Bandura A. A evolução da teoria social cognitiva. In: Bandura A, Azzi R, Polydoro SAJ, organizadores. Teoria social cognitiva: conceitos básicos. Porto Alegre: Editora Artmed; 2008. p. 15-41.

7. Bandura A. Self-efficacy: the exercise of control. New York: W.H. Freeman; 1997.

8. Bandura A. Social foundations of thought and action: a social cognitive theory. Englewood Cliffs: Prentice Hall; 1986. 
9. Bandura A. Self-efficacy in changing societies. Cambridge: Cambridge University Press; 1995.

10. Bandura A. Self-efficacy. In: Ramachaudran VS, editor. Encyclopedia of human behavior. New York: Academic Press; 1994. p. 71-81.

11. Schwarzer R, Fuchs R. Self-efficacy and health behaviors. In: Conner M, Norman P, editores. Predicting health behavior: research and practice with social cognition models. Buckingham: Open University Press; 1996. p. 163-96.

12. Connor JP, George SM, Gullo MJ, Kelly AB, Young RM. A prospective study of alcohol expectancies and self-efficacy as predictors of young adolescent alcohol misuse. Alcohol Alcohol 2011; 46:161-9.

13. Bandura A. Health promotion form the perspective of social cognitive theory. In: Norman P, Abraham C, Conner M, editors. Understanding and changing health behavior. Amsterdam: Harwood Academic Press; 2000. p. 299-339.

14. Luszczynska A, Schwarzer R. Multidimensional health locus of control: comments on the construct and its measurement. J Health Psychol 2005; 10:633-42.

15. Chariyeva Z, Golin CE, Earp JA, Maman S, Suchindran C, Zimmer C. The role of self-efficacy and motivation to explain the effect of motivational interviewing time on changes in risky sexual behavior among people living with HIV: a mediation analysis. AIDS Behav 2013; 17:813-23.

16. Alvy LM, McKirnan DJ, Mansergh G, Koblin B, Colfax GN, Flores SA, et al. Depression is associated with sexual risk among men who have sex with men, but is mediated by cognitive escape and selfefficacy. AIDS Behav 2011; 15:1171-9.

17. Ashford S, Edmunds J, French DP. What is the best way to change self-efficacy to promote lifestyle and recreational physical activity? A systematic review with meta-analysis. Br J Health Psychol 2010; 15(Pt 2):265-88.

18. Glasofer DR, Haaga DA, Hannallah L, Field SE, Kozlosky M, Reynols J, et al. Self-efficacy beliefs and eating behavior in adolescent girls at-risk for excess weight gain and binge eating disorder. Int $\mathrm{J}$ Eat Disord 2013; 46:663-8.

19. Schnoll RA, Martinez E, Tatum KL, Glass M, Bernath A, Ferris D, et al. Increased self-efficacy to quit and perceived control over withdrawal symptoms predict smoking cessation following nicotine dependence treatment. Addict Behav 2011; 36:144-7.

20. Roddenberry A, Renk K. Locus of control and selfefficacy: potential mediators of stress, illness, and utilization of health services in college students. Child Psychiatry Hum Dev 2010; 41:353-70.

21. Terry DJ. Determinants of coping: the role of stable and situational factors. J Pers Soc Psychol 1994; 66:895-910.

22. Cheung SK, Sun SYK. Effects of self-efficacy and social support on the mental health conditions of mutual-aid organization members. Soc Behav Pers 2000; 28:413-22.
23. Karademas EC, Kalantzi-Azizi A. The stress process, self-efficacy expectations, and psychological health. Pers Individ Dif 2004; 37:1033-43.

24. Costa M, Accioly Júnior H, Oliveira J, Maia E. Estresse: diagnóstico dos policiais militares em uma cidade brasileira. Rev Panam Salud Pública 2007; 21:217-22.

25. Murta SG, Tróccoli BT. Stress ocupacional em bombeiros: efeitos de intervenção baseada em avaliação de necessidades. Estud Psicol (Campinas) 2007; 24:41-51.

26. Minayo MCS, Souza ER, Constantino P. Riscos percebidos e vitimização de policiais civis e militares na (in)segurança pública. Cad Saúde Pública 2011; 23:2767-79.

27. Souza ER, Franco LG, Meireles CC, Ferreira VT, Santos NC. Sofrimento psíquico entre policiais civis: uma análise sob a ótica do gênero. Cad Saúde Pública 2007; 23:105-14.

28. Ryan RM, Deci EL. Self-determination theory and the facilitation of intrinsic motivation, social development, and well-being. Am Psychol 2001; 55:68-78.

29. Diener E, Chan MY. Happy people live longer: subjective well-being contributes to health and longevity. Appl Psychol Health Well Being 2011; 3:1-43.

30. Lyubomirsky S, Kind L, Diener E. The benefits of frequent positive affect: does happiness lead to success? Psychol Bull 2005; 131:803-55.

31. Bisschop MI, Knegsman DMW, Beekman ATF, Deeg DJH. Chronic diseases and depression: the modifying role of psychosocial resources. Soc Sci Med 2004; 59:721-33.

32. Parto M, Besharat MA. The direct and indirect effects of self-efficacy and problem solving on mental health in adolescents: assessing the role of coping strategies as mediating mechanism. Procedia Soc Behav Sci 2011; 30:639-43

33. Kashdan TB, Roberts JE. Social anxiety's impact on affect, curiosity, and social self-efficacy during a high self-focus social threat situation. Cognit Ther Res 2004; 28:119-41.

34. Bandura A, Caprara GV, Barbaranelli C, Gerbino $\mathrm{M}$, Pastorelli C. Role of affective self-regulatory efficacy in diverse spheres of psychosocial functioning. Child Dev 2003; 74:769-82.

35. Goldberg D, Williams P. A users guide to the General Health Questionnaire. Windsor: NFER-Nelson; 1988.

36. Schwarzer R, Jerusalem M. Generalized self-efficacy scale. In Weinman J, Wright S, Johnston M, editors. Measures in health psychology: a user's portfolio. Windsor: NFER-NELSON; 1995. p. 35-7.

37. Diener E, Emmons RA. The independence of positive and negative affect. J Pers Soc Psychol 1984; 47:1105-17.

38. Chaves SSS. Valores como preditores do bem-estar subjetivo [Dissertação de Mestrado]. João Pessoa: Departamento de Psicologia, Universidade Federal da Paraíba; 2003. 
39. Ryan RM, Frederick CM. On energy, personality and health: subjective vitality as a dynamic reflection of well-being. J Pers 1997; 65:259-65.

40. Diener E, Emmons RA, Larsen RJ, Griffin S. The satisfaction with life scale. J Pers Assess 1985; 49:71-5.

41. Baron RM, Kenny DA. The moderator-mediator variable distinction in social psychological research: conceptual, strategic and statistical considerations. J Pers Soc Psychol 1986; 51:1173-82.

42. Little TD, Card NA, Boivard JA, Preacher KJ, Crandall CS. Structural equation modeling of mediation and moderation with contextual factors. In: Little TD, Bovaird JA, Card NA, editors. Modeling contextual effects in longitudinal studies. Mahwah: Lawrence Erlbaum Associates; 2007. p. 207-30.

43. Sobel ME. Asymptotic confidence intervals for indirect effects in structural equation models. In: Leinhardt S, editor. Sociological methodology. Washington DC: American Sociological Association; 1982. p. 290-312.

44. Preacher KJ, Hayes AF. Asymptotic and resampling strategies for assessing and comparing indirect effects in multiple mediator models. Behav Res Methods 2008; 40:879-91.

45. MacKinnon DP, Lockwood CM, Williams J. Confidence limits for the indirect effect: distribution of the product and resampling methods. Multivariate Behav Res 2004; 39:99-128.
46. Hayes AF. Introduction to mediation, moderation, and conditional process analysis: a regressionbased approach. New York: The Guilford Press; 2013.

47. Gouveia VV, Lima TJS, Gouveia RSV, Freires LA, Barbosa LHGM. Questionário de Saúde Geral (QSG-12): o efeito de itens negativos em sua estrutura factorial. Cad Saúde Pública 2012; 28:375-84.

48. Chariyeva Z, Golin CE, Earp JA, Maman S, Suchindran C, Zimmer C. The role of self-efficacy and motivation to explain the effect of motivational interviewing time on changes in risky sexual behavior among people living with HIV: a mediation analysis. AIDS Behav 2013; 17:813-23.

49. Axelsson M, Lötvall J, Cliffordson C, Lundgren J, Brink E. Self-efficacy and adherence as mediating factors between personality traits and health-related quality of life. Qual Life Res 2013; 22:567-75.

50. Ferreira CA. Análise pericial do padrão de consume de álcool em policiais e seus fatores de risco. Revista Especialize On-line IPOG 2013; 5(1). http://www.ipog.edu.br/nao-aluno/revista-ipog/ artigos/edicao-n-5-2013.

51. Evans O, Steptoe A. The contribution of genderrole orientation, work factors and home stressors to psychological well-being and sickness absence in male- and female-dominated occupational groups. Soc Sci Med 2002; 54:481-92.

Submitted on $14 /$ Oct $/ 2013$

Final version resubmitted on 21/May/2014

Approved on 04/Jun/2014 